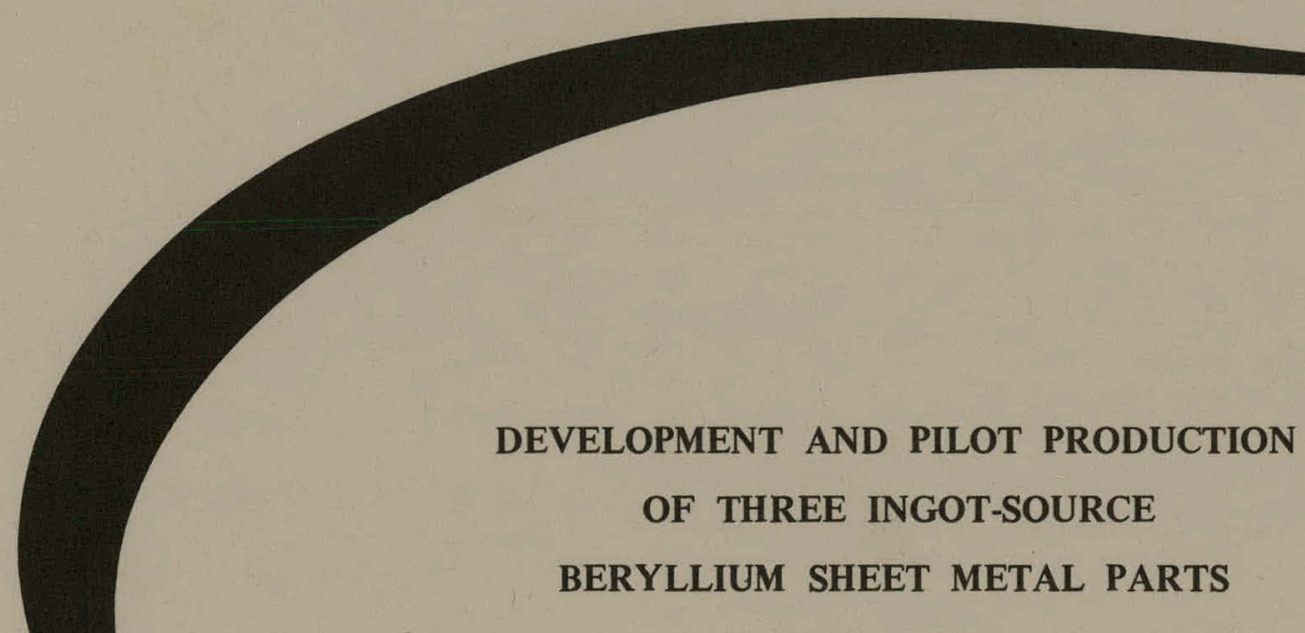

Dennis R. Floyd

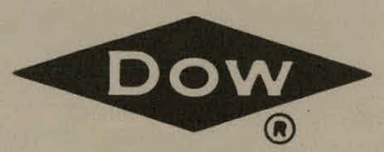

DOW CHEMICAL U.S.A. ROCKY FLATS DIVISION

P. O. BOX 888

GOLDEN, COLORADO 80401

U. S. ENERGY RESEARCH AND DEVELOPMENT ADMINISTRATION CONTRACT AT(29-1)-1106 


\section{DISCLAIMER}

This report was prepared as an account of work sponsored by an agency of the United States Government. Neither the United States Government nor any agency Thereof, nor any of their employees, makes any warranty, express or implied, or assumes any legal liability or responsibility for the accuracy, completeness, or usefulness of any information, apparatus, product, or process disclosed, or represents that its use would not infringe privately owned rights. Reference herein to any specific commercial product, process, or service by trade name, trademark, manufacturer, or otherwise does not necessarily constitute or imply its endorsement, recommendation, or favoring by the United States Government or any agency thereof. The views and opinions of authors expressed herein do not necessarily state or reflect those of the United States Government or any agency thereof. 


\section{DISCLAIMER}

Portions of this document may be illegible in electronic image products. Images are produced from the best available original document. 


\section{LEGAL NOTICE}

This report was prepared as an account of work sponsored by the United States Government. Neither the United States nor the Energy Research and Development Administration, nor any of their employees, nor any of their contractors, subenntracicors, or their cmployees, makes any warranty, expressed or implied, or assumes any legal liability or responsibility for the accuracy, completeness or usefulness of any information, apparatus, product or process disclosed, or represents that its use would not infringe privately owned rights.

Printed in the United States of America

Available from the

National Technical Information Service

U. S. Department of Commerce

Springfield, Virginia 22151

Price: Printed Copy $\$ 4.00$ Microfiche $\$ 2.25$ 


\title{
DEVELOPMENT AND PILOT PRODUCTION OF THREE INGOT-SOURCE BERYLLIUM SHEET METAL PARTS
}

\author{
Dennis R. Floyd
}

Materials Technology Research and Development GENERAL METALLURGY

\author{
DOW CHEMICAL U.S.A. \\ ROCKY FLATS DIVISION \\ P. O. BOX 888 \\ GOLDEN, COLORADO 80401 \\ Prepared under Contract AT(29-1)-1106 \\ for the \\ Albuquerque Operations Office
}

U.S. Energy Research and Development Administration

Beryllium

Cold Working

Tensile Properties

Wrought Metals

Yield Strength

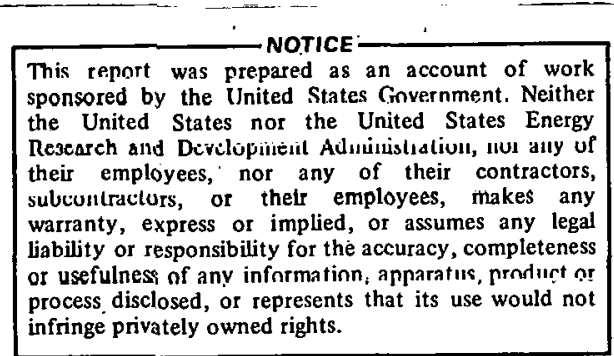


RFP-1827 


\section{CONTENTS}

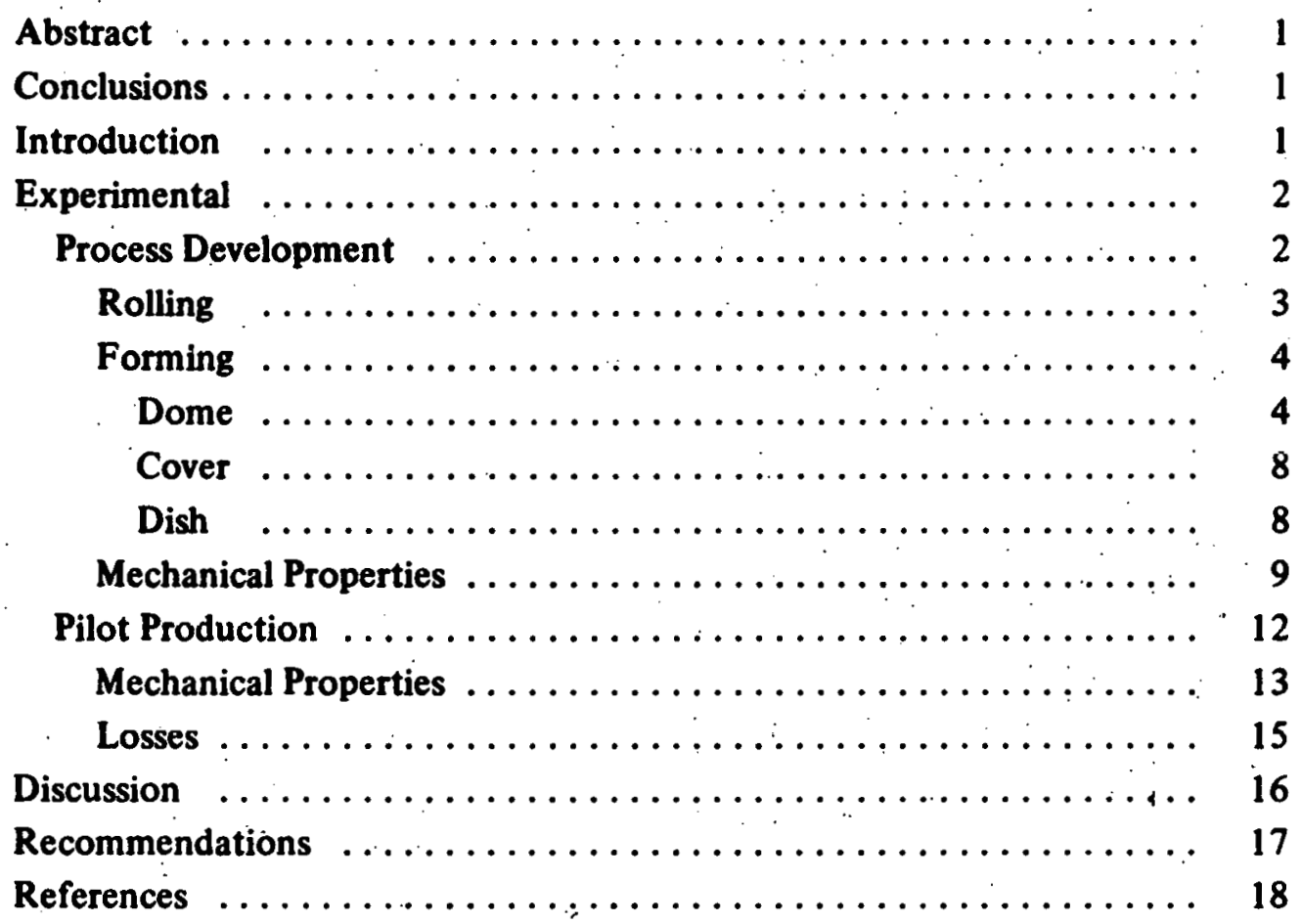




\section{IS T O F F I G UR E S}

1. Cross-sections of the three furmed parts $\ldots \ldots \ldots \ldots \ldots \ldots \ldots$

2. Size of beryllium present at various stages in rolling $\ldots \ldots \ldots \ldots 5$

3. Forming method used for the Dome component .......... 6

4. Photograph of an as-formed Dome ............. 7

5. Photograph of two finished Domos . . . . . . . . . . . . . . . . 7

6. Forming method used for the Cover $\ldots \ldots \ldots \ldots \ldots$

7. Photograph of two finished Covers $\ldots \ldots \ldots \ldots \ldots$

8. Fonning method used for the Dish . . . . . . . . . . 9

9. Photograph showing three fabrication stages of the Dish $\ldots \ldots \ldots 10$

10. Plot of tensile properties versus heat-treat tcmpcrature for 0.1 -inch-thick ingot sheet $\ldots \ldots \ldots \ldots \ldots \ldots$ 


\section{I S T. OF TAB LES}

1. Typical chemistry of beryllium billets $\ldots \ldots \ldots \ldots \ldots \ldots \ldots \ldots 2$

2. Tensile properties at various sheet thicknesses $\ldots \ldots \ldots \ldots \ldots$

3. Tensile properties of 0.170 -inch-thick sheet $\ldots \ldots \ldots \ldots \ldots$

4. Tensile properties of 0.170 -inch-thick sheet as a function of various recovery-type heat treatments $\ldots \ldots \ldots 11$

5. Tensile properties of deep-drawn parts $\ldots \ldots \ldots \ldots \ldots \ldots \ldots \ldots$

6. Summary of pilot production tensile results $\ldots \ldots \ldots \ldots \ldots \ldots$

7. Statistical summary of pilot production data $\ldots \ldots \ldots \ldots$

8. Variation of tensile properties within one sheet at each sheet thickness used for a Part set ........ 15

9. Summary of losses in the pilot production run $\ldots \ldots \ldots 16$

10. Mechanical properties of ingot-source and powder-source beryllium $\ldots \ldots \ldots \ldots \ldots 17$ 


\section{A C K N OW LED GM EN T S}

Many of the rolling and forming developments resulted from the excellent work of W. W. Leslie. Leslie was also responsible, along with A. D. Mills, for coordinating the pilot production run. O. A. Lee and D. L. Fergason did the development work for the forming of the Dish and Cover configurations, respectively. O. A. Lee also investigated the response of yield strength to heat treat conditions.

Tensile testing was done by R. W. Brugger and G. G. Gauger under thè äble supervision of D. V. Miley. Statistical analyses were provided by D. Childerston.

The author recognizes the important contributions of the individuals mentioned above, and is sincerely appreciative of their help. 


\title{
DEVELOPMENT AND PILOT PRODUCTION OF THREE INGOT-SOURCE BERYLLIUM SHEET METAL PARTS
}

\author{
Dennis R. Floyd
}

\begin{abstract}
Results of an extensive development program aimed at making three, separate, structural components from beryllium, using sheet-metal fabrication methods, are presented. Ingot-source beryllium sheet at thicknesses of $0.100,0.125$, and 0.170 inch is formed in a fully-recrystallized and in a partially-recrystallized condition. The tensile yield strength is 26,000 psi after full recrystallization. After partial recrystallization, tensile yield strength is between 35,000 and 45,000 psi, depending upon sheet thickness, heat treat temperature, and time at temperature. The high yield strength is retained in the parts after forming.
\end{abstract}

Also reported are results of a pilot production run aimed at making 48 each of the three configurations. The process for making parts from the 0.100 and 0.125 -inch thick sheet is considered viable for production. The process requiring 0.170 -inch thick sheet is suitable only as a backup production process since the tensile properties at this thickness are close to the minimum requirements of the specification. Statistical analysis of tensile results show that ingot sheet is more uniform than powder-source beryllium that is used to make the same components.

\section{CONCLUSIONS}

1. A process utilizing sheet-metal fabrication methods has been developed for making three parts from high yield strength ingot-sheet beryllium.

2. Results of a pilot production run show that the process for making two of the three parts is viable for production. The process for making the third part may be considered only for backup because of problems in reliably meeting the required strength levels.
3. Results of 650 tensile tests of 54 different sheets show that the yield strength of ingot-sheet beryllium may be retained above 35,000 psi by using a low-temperature, partial-recrystallization anneal after the last rolling pass. A full recrystallization anneal reduces the yield strength to 26,000 psi.

4. The room-temperature tensile properties of high yield strength ingot sheet are more reproducible than room-temperature tensile properties of powder source material that is supplied to the same specification.

\section{INTRODUCTION}

This report summarizes the work done to develop a production process for making three beryllium parts using ingot-source material. The report is written for an audience ranging from designers of the parts to interested people in the beryllium industry, including Rocky Flats personnel concerned with the project.

Requirements specified for the three parts (Dome, Cover, and Dish) changed often during the course of the process development. Ingot sheet was an immediate choice at the beginning because loose dimensional tolerances favored a form-to-size approach and because no strength requirements existed. In addition, a standard process for making similar parts from ingot sheet existed at the time. Periodic design changes ensued. At the present time, dimensional requirements are such that machining is mandatory, and mechanical property requirements demand strength levels above those normally found in ingot-source beryllium. The only advantage that ingot-source beryllium might still retain over conventional powder-source beryllium for this application is lower cost. 
The report contains two main sections: Process Development and Pilot Production. Process Development describes the rolling and forming techniques that were developed for these components. The method of increasing the sheet's mechanical properties to higher strength levels as required in the new specification is also described. Results of a pilot production run aimed at making 48 sets of these three components are discussed in the second section, and recommendations regarding future production are presented.

\section{EXPERIMENTAL}

The basic process for manufacturing sheet-metal parts from ingot-source beryllium has been described previously. 1,2 That process involves vacuum casting solid scrap beryllium into sound ingots, which are sawed and machined into rolling billets. The billets are canned in Type 304 stainless steel and are hot rolled into nominally 0.200 -inch thick sheet. Hot rolling converts the columnar cast structure into an equiaxed microstructure with an average grain size of about 60 micrometres. Subsequent warm rolling of the sheet to nominally 0.100 -inch thick sheet reducés the grain size to an average grain diameter of about 35 inicrumeties. The warm rolling is done "bare," that is, the sheet is first removed from the rolling can.

Once the desired thickness is obtained by rolling, the material is annealed, and forming blanks are cut from the sheet. This can be done by heating the sheet followed by blanking a circular disc or by lathe cutting at room temperature. Deepdrawing is then carried out on a single-action hydraulic press, using hold-down pressure to prevent wrinkling. The beryllium is preheated in air and is formed with steel tooling that normally consists of a punch, die cavity, and draw ring. The tooling is also heated, and a lubricant is used to prevent galling. Formed parts normally are vacuum heat treated for nine hours at $760^{\circ} \mathrm{C}$ and subsequently are machined to closer dimensional tolerances than can be obtained in deep-drawirig. Chemical milling is often used as the final metal removal step to eliminate machining damage that, if not removed, greatly reduces the ductility of beryllium.
TABLE 1. A Comparison of the Maximum Allowable Impurity Content With the Mean Value for Each Impurity That Results from the Standard Ingot-Sheet Beryllium Process.

\begin{tabular}{|c|c|c|c|}
\hline Impurity* & $\begin{array}{c}\text { Maximum } \\
\text { Allowable } \\
\text { (ppm) }\end{array}$ & $\begin{array}{l}\text { Process Mean } \\
\quad(\mathrm{ppm})\end{array}$ & $\begin{array}{c}\text { Standard } \\
\text { Deviation } \\
\text { (ppm) }\end{array}$ \\
\hline Beryllium Oxide & 500 & 50 & 0 \\
\hline Carbon & 1200 & 720 & 110 \\
\hline Nitrogen & 600 & $<100$ & - \\
\hline Iron & 2500 & 1450 & 50 \\
\hline Aluminum & 1200 & 660 & 40 \\
\hline Silicon & 1200 & 520 & 70 \\
\hline Magnesium & 500 & $<10$ & - \\
\hline Nickel & 500 & 210 & 50 \\
\hline Titanium & 500 & 250 & 50 \\
\hline Copper & 500 & $<100$ & \\
\hline Chromium & 500 & $<200$ & \\
\hline
\end{tabular}

*Any other single metallic impurity shall not exceed $200 \mathrm{ppm}$. The minimum iron content shall be 1.5 times the aluminum content.

The process used to make the material for the present parts is similar to that described above for standard ingol-sheet niaterial, and the samc rolling billels ate used. Typical chcmistry of theso billets is given in Table 1. The rolling practice is identical except for minor changes in the final passes.

These changes are needed because the thickness of the sheet required to make each part is different. The changes are described later in this report. Forming practices also are the same, basically, as those practices used for standard ingot-sheet material. Some adjustments are required if the beryllium sheet must be formed in its high yicld strength condition. These adjustments also are described later in this report.

\section{Process Development}

Summarized in this section are the results of rolling, forming, and heat-treating experiments aimed at developing a process for making the three parts shown in Figure 1. The dimensions given in this figure are only approximate. The parts must be machined, after forming, to a maximum wall thickness of $0.140,0.048$, and 0.025 inch for the 


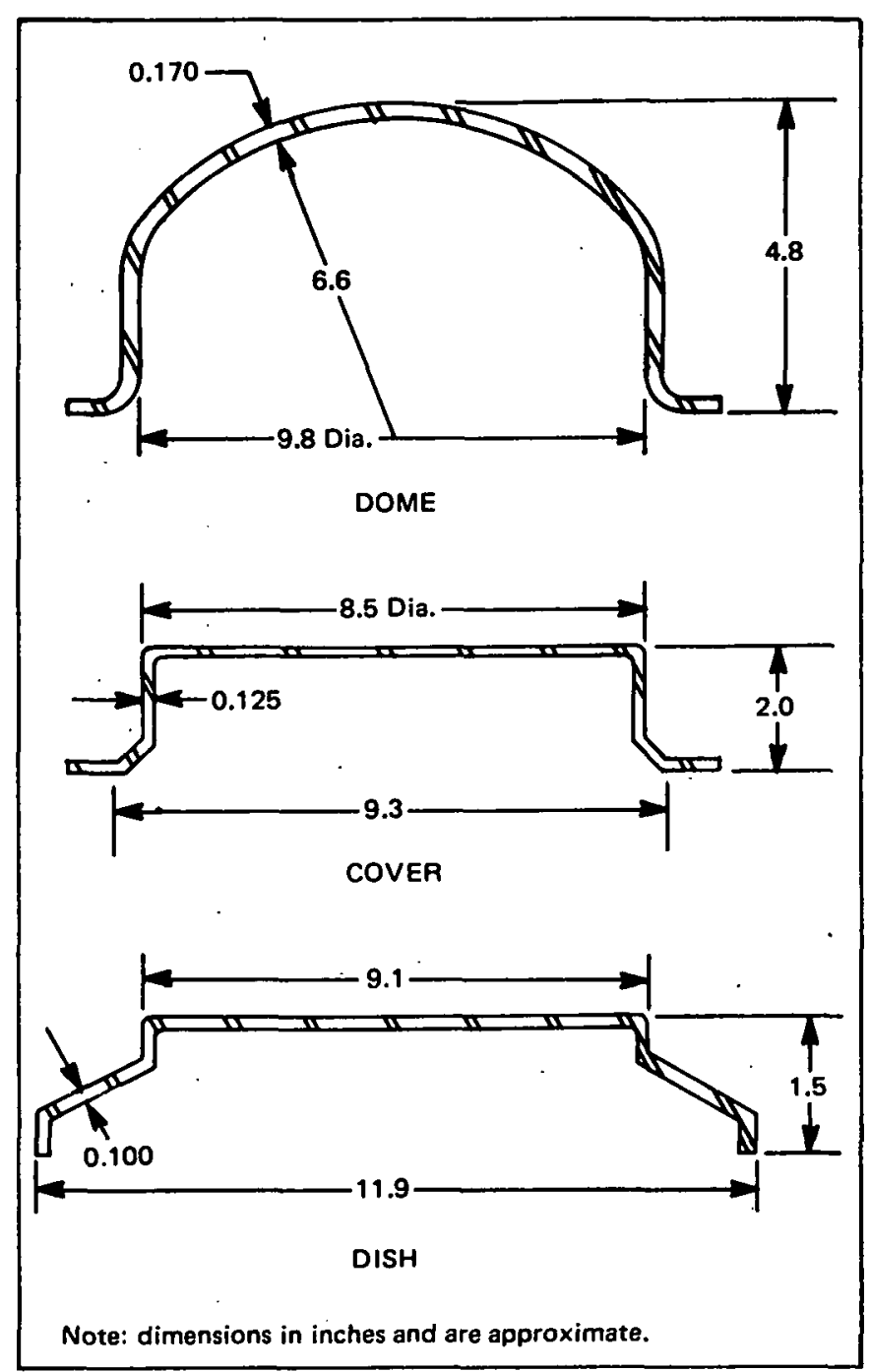

FIGURE 1. Cross-Sections of the Three Formed Parts.

Dome, Cover, and Dish, respectively. Part thickness is important because it dictates the gauge to which the sheet is rolled prior to deep-drawing. Several factors make it desirable to use the thinnest sheet possible. As the sheet is reduced in thickness by rolling, it elongates. This can result in an increased number of forming blanks from each sheet.

Secondly, the strength and ductility of the sheet improves as the thickness decreases because of the grain refinement attendant with increased rolling reduction. Thirdly, thin sheet can be drawn around ighter radii and can be forced into sharper corners luring deep drawing than can thicker material.
Finally, the time and material waste associated with machining is minimized as the formed-part thickness approaches the finish-machined part thickness.

The diameters and depths of parts shown in Figure 1 are important in determining the diameter of the forming blank that is needed. The radii at the locations on the parts where contours change are important because these radii control the severity of bending that is demanded of the material in deep-drawing.

Although most of this section is devoted to the fabrication of the three parts given in Figure 1, some of the earlier designs will be discussed since they influenced the eventual forming method. Results for each part type (Dome, Cover, and Dish) are included in the rolling, forming, and mechanical property sections that follow.

\section{Rolling}

The major challenge in rolling development is to produce balanced mechanical properties at the required sheet thickness. This is necessary to ensure good formability in deep-drawing and to provide predictable service behavior. The wall thickness of parts shown in Figure 1 requires sheet that is $0.170,0.125$, and 0.100 inch thick for the Dome, Cover, and Dish, respectively. Mechanical properties of material produced by the standard rolling practice and by being annealed 8 to 10 hours at $760^{\circ} \mathrm{C}$ in vacuum are shown in Table 2 as a function of sheet thickness. The longitudinal and transverse properties are shown in Table 2 as being well-balanced at 0.125 inch thick, close at $0.100 \mathrm{inch}$, and poor at 0.200 inch.

The key to obtaining balanced mechanical properties is to get an equal amount of work in the rolling direction and in the direction transverse to it. Equal work refers to the combined effect of rolling temperature and of percent reduction in thickness. In the standard can-rolling practice, cross rolling involves rotating the sheet $90^{\circ}$ after each pass until the sheet measures 25 by 25 by 0.405 inches as shown in Figure 2. The next four passes are in a common direction at $760{ }^{\circ} \mathrm{C}$ 
with a total reduction in thickness of 48 percent. This unidirectional rolling causes the mechanical properties at the 0.200 -inch thickness to be higher in the rolling direction than in the transverse direction, as shown in Table 2. Bare rolling is done at $727^{\circ} \mathrm{C}$ in a direction transverse to the can-rolling direction to bring these properties into balance. Since the bare rolling is done at a lower temperature than can rolling, less reduction in thickness is required to achieve balanced properties than the $48 \%$ reduction used in unidirectional can rolling.

As is evident in Table 2, the balance is present in 0.125 -inch thick sheet, which corresponds to 38 percent reduction. This thickness is obtained in four rolling passes, each pass causing about 15 percent reduction in thickness. If a fifth pass is used, which reduces the sheet to 0.100 inch thickness and corresponds to 52 percent total reduction, the properties become superior in the bare-rolling direction, as seen in Table 2 .

The reason for the dependence of mechanical properties on rolling direction is probably preferred crystallographic orientation that is developed during rolling. Texture studies of the standard 0.200-inchthick sheet show that the population of basal planes in the plane of the sheet is about 2.5 times random, and the number of first-order prism planes aligned with their poles in the rolling direction is about two times the number expected in a randomly oriented sample. ${ }^{3}$ This texture may give rise to the phenomenon of duplex slip, where flow occurs alternately on one and then another family of slip planes in those grains in which first-order prism planes are so oriented. ${ }^{4}$ Duplex slip causes an increase in the elongation to fracture and, through strain hardening, a commensurate increase in fracture strength. Both of these increases are evident in the rolling direction of the 0.2 -inchthick sheet with properties as listed in Table 2.

Returning to the thicknesses used in this work $(0.170,0.125$, and 0.100 inch $)$, only the 0.170 inch-thick material needs improvement. The properties at $0.125 \mathrm{inch}$ are well balanced, and experience has shown that the imbalance present in 0.100-inch-thick sheet is not harmful. To achieve a good balance of mechanical properties
TABLE 2. Changes in Room-Temperature Tensile Properties of Standard Material that is Bare-Rolled.*

\begin{tabular}{|c|c|c|c|c|c|}
\hline $\begin{array}{c}\text { Sheet } \\
\text { Thickness } \\
\text { (in.) }\end{array}$ & $\begin{array}{c}\text { Amount of } \\
\text { Reduction } \\
\text { By Bare } \\
\text { Rolling } \\
(\%)\end{array}$ & $\begin{array}{c}\text { Test } \\
\text { Direction** }\end{array}$ & $\begin{array}{l}\text { Ultimate } \\
\text { (ksi) }\end{array}$ & $\begin{array}{c}0.2 \% \\
\text { Offset } \\
\text { Yield } \\
(\mathrm{ksi})\end{array}$ & $\begin{array}{c}\text { Elongation } \\
(\%)\end{array}$ \\
\hline \multirow[t]{2}{*}{0.200} & 0 & $\mathbf{L}$ & 42.4 & 25.6 & 2.7 \\
\hline & & $\mathbf{T}$ & 30.2 & 21.8 & 1.9 \\
\hline \multirow[t]{2}{*}{0.125} & 38 & $\mathbf{L}$ & 43.0 & 25.0 & 5.0 \\
\hline & & $\mathrm{T}$ & 43.0 & 25.0 & 5.0 \\
\hline \multirow[t]{2}{*}{0.100} & 50 & L & 49.7 & 26.1 & 6.2 \\
\hline & & $\mathrm{T}$ & 43.7 & 26.0 & 4.9 \\
\hline
\end{tabular}

*All material is anuealed a minimum of cight hour's subsequent to rolling.

**These arc longitudinal (L) and transverse (T) to the rolling direction in the final pass. The bare-rolling direction is $90^{\circ}$. to the roiling direction for the previuus foul can-rolling passog.

in 0.170 -inch-thick sheet, can-rolling is stopped at 0.3 inch, and bare-rolling is done at $760^{\circ} \mathrm{C}$. This means that about $26 \%$ reduction is done at $760{ }^{\circ} \mathrm{C}$ by can-rolling and about $43 \%$ reduction is done by bare-rolling. The data in Table 3 for a typical sheet rolled in this manner show reasonably good balance in properties.

\section{Forming}

Dome

Originally the Dome part was to have a uniform 0.025 -inch-thick wall and tolerances of \pm 0.010 inch on the contour. These tolerances are sufficiently open that forming directly to size becomes an attractive option. This itequires a forming blank about 16 inches in diameter by 0.030 inch thick, and such a large diameter-to-thickness ratio $(D / t)$ is difficult to form by one-stage deep-drawing. This difficulty arises from the hold-down force necessary to prevent wrinkling becoming so large that the blank will not flow into the cavity as the punch pushes on the blank. Instead of flowing into the cavity, the blank stretches out until it eventually ruptures. 


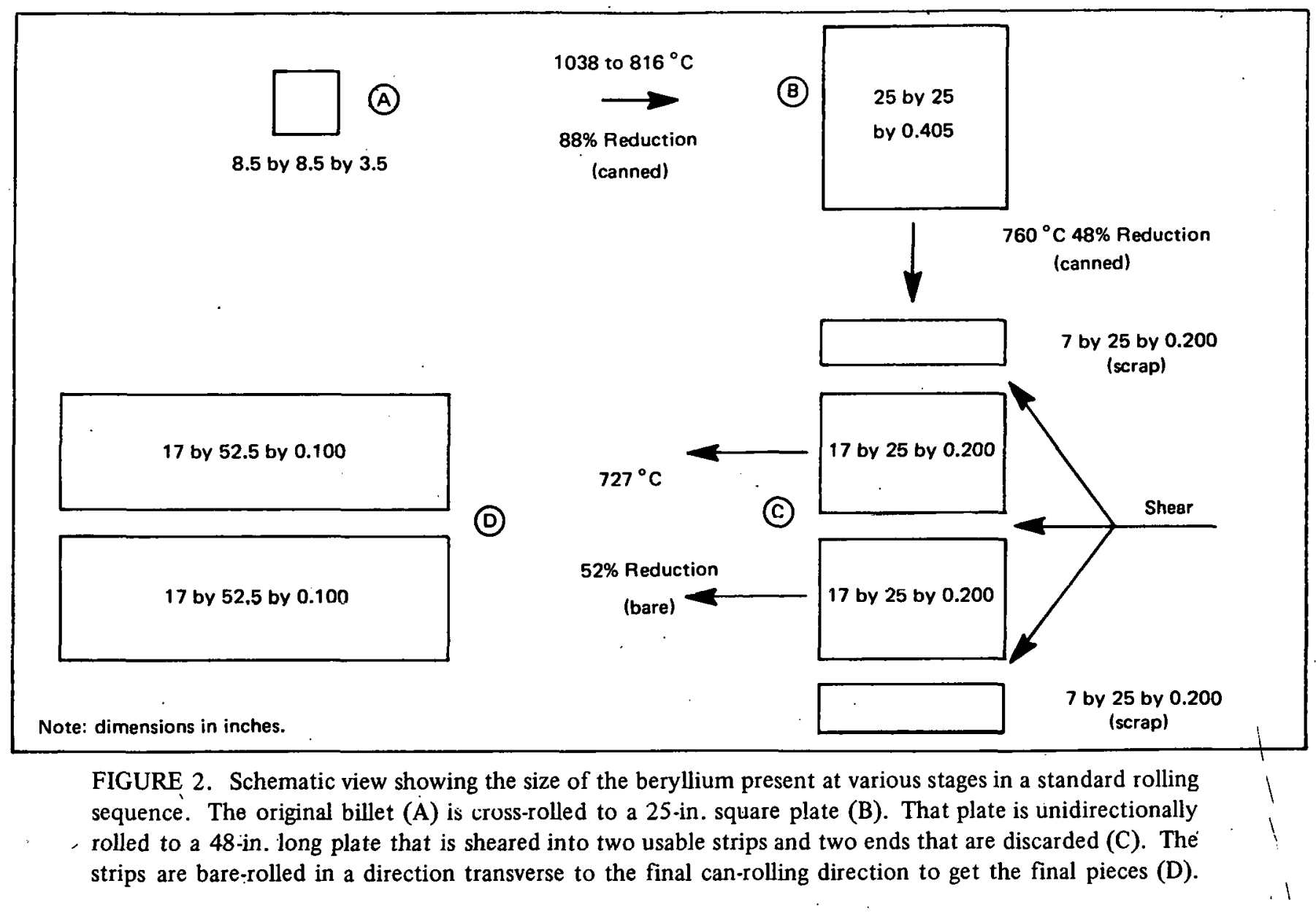

TABLE 3. Room temperature tensile properties of Beryllium Ingot Sheet 501906, which was can-rolled to 0.300 inch, turned $90^{\circ}$, bare-rolled to $0.170 \mathrm{inch}$, and annealed at $760^{\circ} \mathrm{C}$ for nine hours. Data are averages of three test results.

\begin{tabular}{ccccc} 
Orientation & $\begin{array}{c}\text { Ultimate } \\
(\mathrm{ksi})\end{array}$ & & $\begin{array}{c}0.2 \% \text { Offset } \\
\text { Yield (ksi) }\end{array}$ & $\begin{array}{c}\text { Elongation } \\
(\%)\end{array}$ \\
\cline { 5 - 6 } Longitudinal & 39.8 & & 22.3 & 4.4 \\
Transverse & 43.4 & & 24.2 & 3.7 \\
\hline
\end{tabular}

The first tooling was built to accommodate a 16-inch-diameter by 0.090 -inch-thick forming blank. The 0.090-inch clearance provides three options is shown in Figure 3. The way in which the part can be made with the most confidence is to form bare beryllium at 0.090 -inch thickness and remove 0.030 inch from both the inside and outside by machining as shown in Figure 3a. This means that the $\mathrm{D} / \mathrm{t}$ ratio is reduced to 180 , a ratio that gives excellent formability. Only six forming blanks can be made from a standard billet rolled to this 0.090 -inch thickness, whereas 18 blanks can bemade from the same size billet if the forming blank is 0.030 -inch thick. The other two options available with the tool design shown in Figure 3 both use 0.030-inch-thick beryllium.

In the option illustrated in Figure 3b, the beryllium is sandwiched between titanium and mild steel so that the effective $D / t$ ratio is still 180 . The forming is done hot, and since, on cooling, titanium contracts less and mild steel slightly more than beryllium, the laminate should separate easily. In addition, 


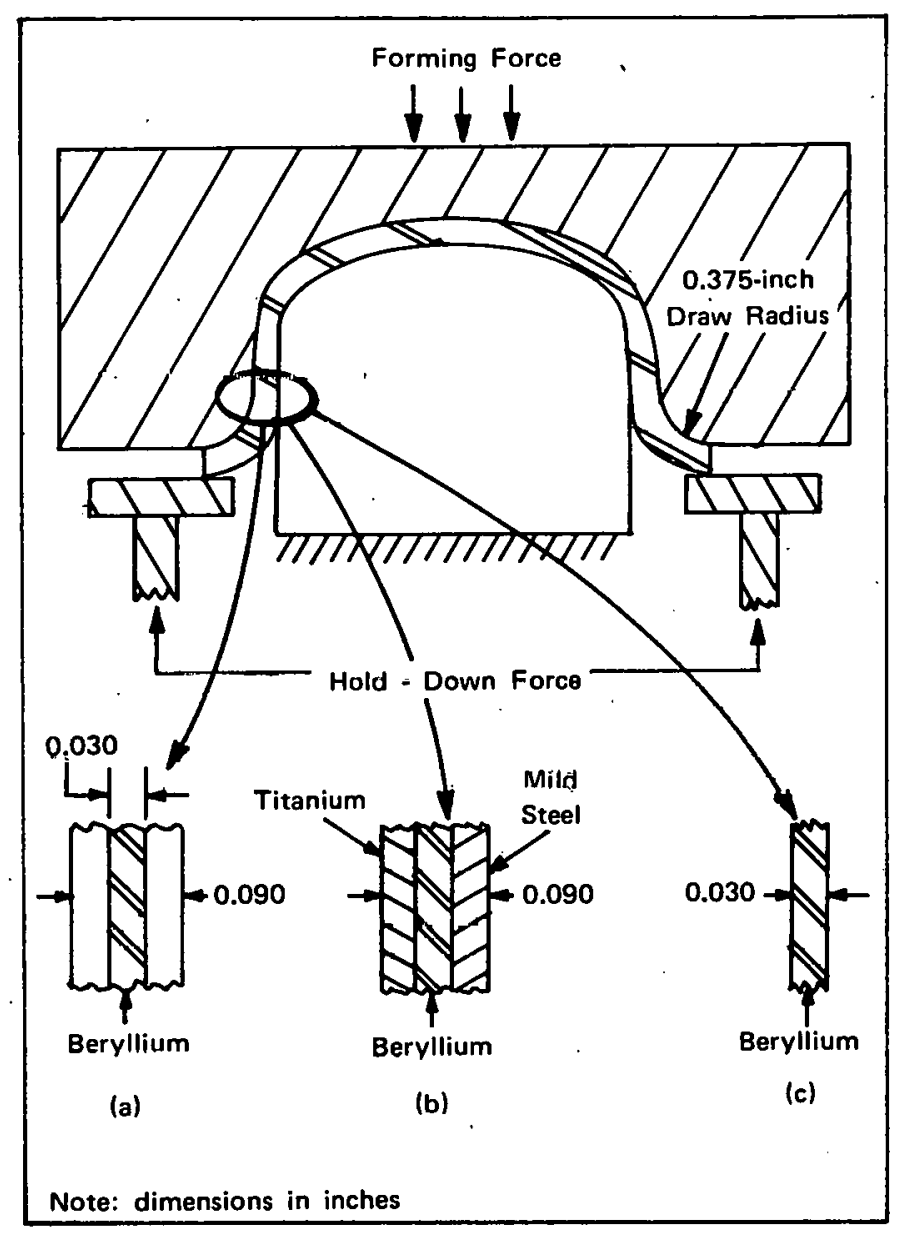

FIGURE 3. Schematic cross-sectional view of the first tooling used to make the Dome part. The throo forming optinns available with this tưol are shown in the (a), (b), and (c) cutaways.

the springback of titanium after forming facilitates separation. In the other option (Figure $3($ ) , a single 0.030 -inch-thick forming blank, having a $D / t$ ratio of 530 , is formed. Although this option will not make the proper contour, it serves to demonstrate whether such high $\mathrm{D} / \mathrm{t}$ ratios can be formed. Tooling designed for 0.030 -inch clearance then can be made and used for more accurate sizing of the contour.

Soon after the tooling was made, the design was changed. A tolerance of \pm 0.002 inch on the contour was required compared to the earlier $\pm 0.010 \mathrm{inch}$. This meant that the option of machining to size was the only one that could be used. Several acceptable parts were made in this manner. To test the concept of forming to size, the other two options were pursued. Both options succeeded. A photograph of the part formed from 0.030 -inch-thick gauge, with a $\mathrm{D} / \mathrm{t}$ ratio of 530 , is shown in Figure 4. Some wrinkling can be seen in the flange of this part, but the wrinkling did not carry over into the useable portion of the part. Although the three-metal laminate formed easily and the titanium overlay was easily removed, problems occurred in separating the beryllium from the mild steel underlay. When a two-metal laminate consisting of titanium and beryllium was formed, the resulting beryllium part was wrinklefree and the two metals separated easily.

Eventually the wall thickness of the forming blank had to be increased to $0.170 \mathrm{inch}$. This increase allowed for a thick section that was later included in the Dome design. The forming tooling shown in Figure 3 was modified to accept the thicker blank. The draw radius was kept at 0.375 inch, and several parts were made successfully with a draw radius-toforming blank thickness $(r / t)$ ratio of about 2 . Two such parts are shown in Figure 5.

An $r / t$ ratio of 2 represents a relatively tight corner to draw sheet metal parts around. This ratio helps control wrinkling and to maintain close forming tolèrances, su $1 / \mathrm{l}+$ atios of 2 to 1 are used consisfertily with fully annealed, ingot-sheet beryllium. An attcmpt was made to deep-draw cross-rolled sheet of powder metallurgy origin, but the $r / t$ ratio of 2 was too severe, and the parts cracked about half way into the draw. Ihe draw radlus was increased to 0.75 inch, and several parts were successlully deep-drawn frum 0.170 -inch-thick stock, which corresponds to an $\mathrm{r} / \mathrm{t}$ ratio of 4.5 .

Forming is done at elevated temperatures. Typically the punch is maintained at $500{ }^{\circ} \mathrm{C}$, the draw ring at $6500^{\circ} \mathrm{C}$, and the forming blanks are preheated to $760{ }^{\circ} \mathrm{C}$. Annular sheets of asbestos, which are first soaked in a colloidal suspension of graphite, are placed beneath and above the forming blank just prior to drawing. These sheets provide good lubrication and help maintain the temperature of the blank during the 20 to 30 second duration of the forming cycle. Once formed, the parts are 


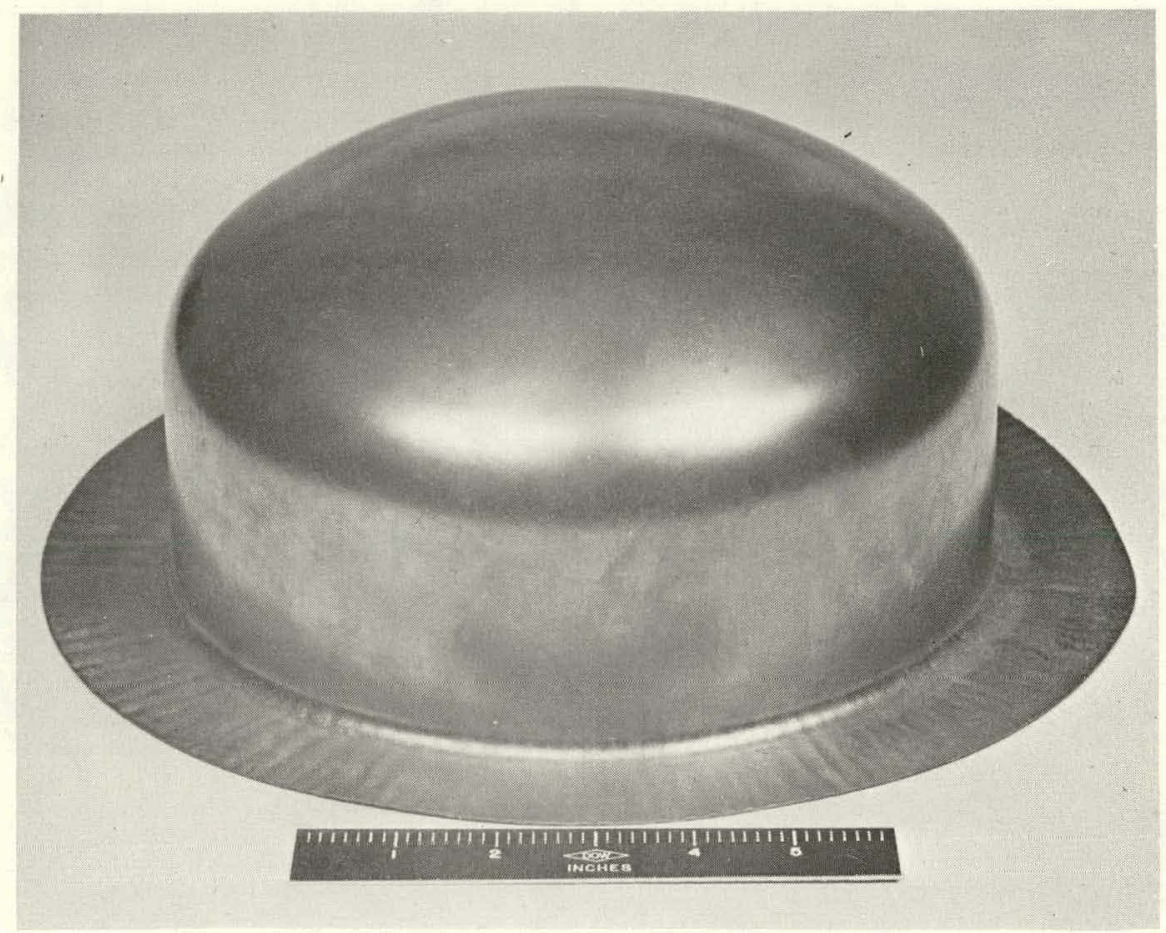

14468-9

FIGURE 4. An Early Dome Part Formed from a 16-Inch-Diameter by 0.030-Inch-Thick Beryllium Blank.

FIGURE 5. Two Typical Parts Made from Ingot Sheet. The Parts Have Been Machined and Chemically-Milled. 16762-12

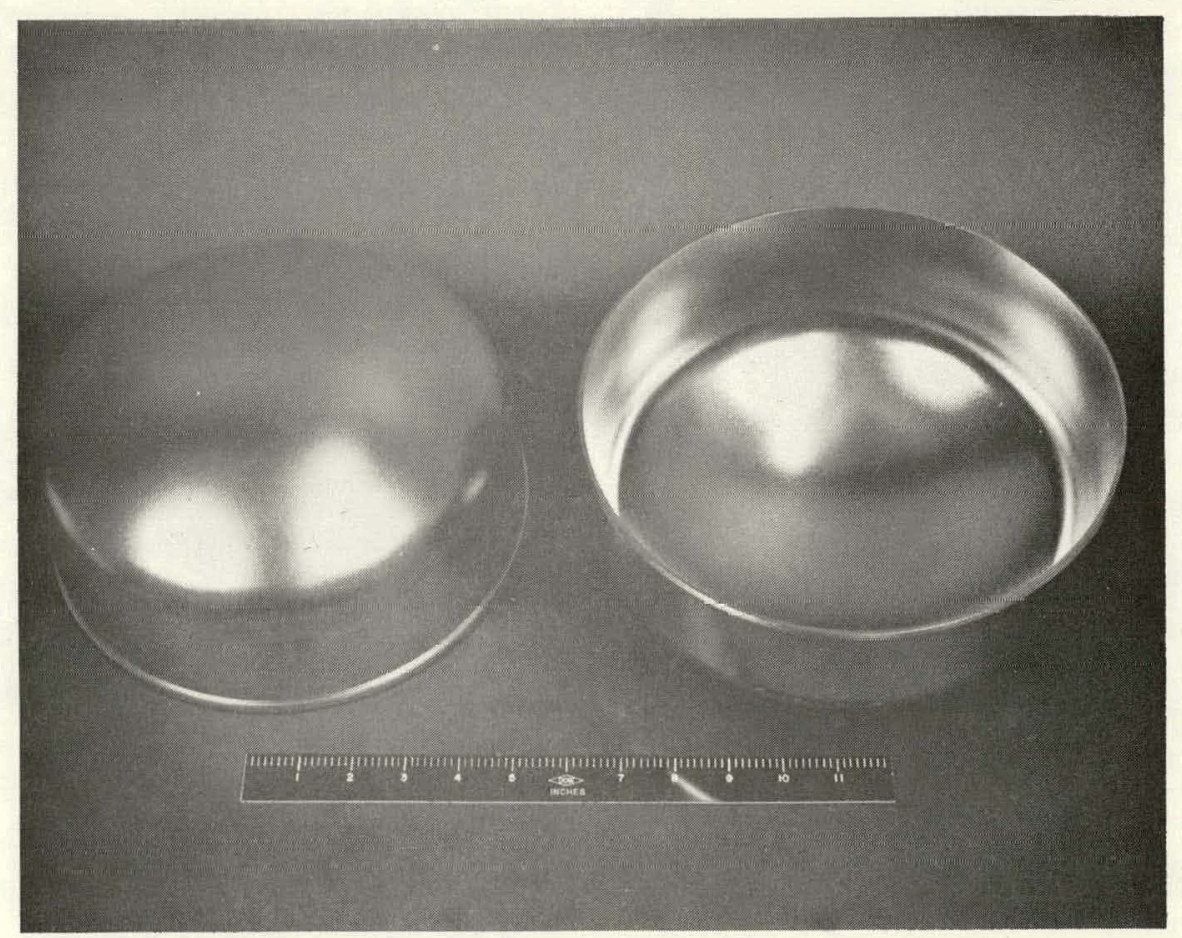




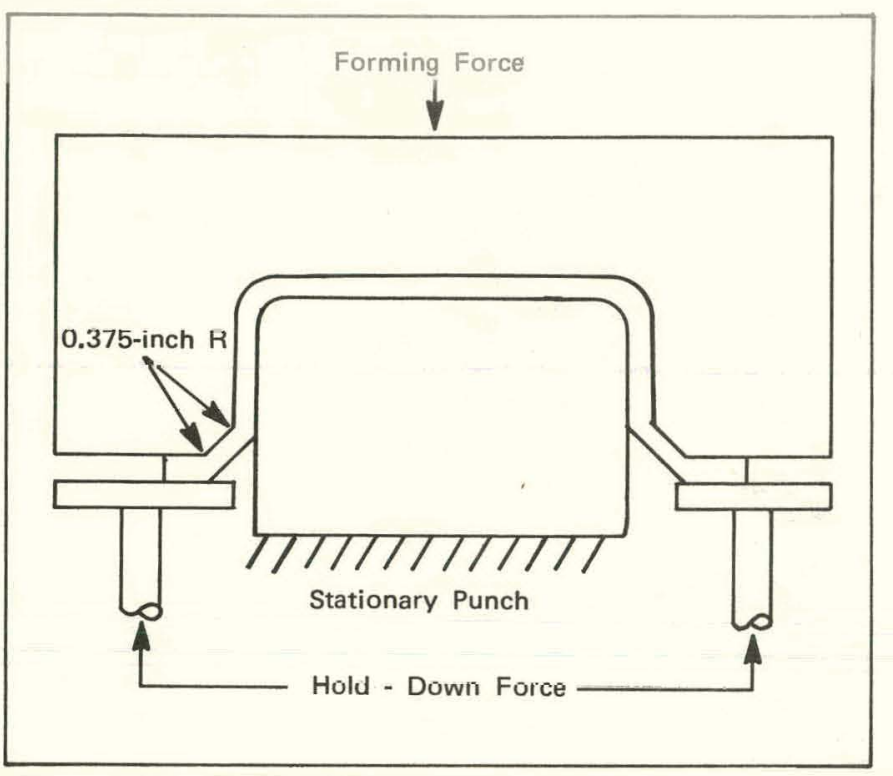

FIGURE 6. Tooling Design for the Cover Part.

stripped off the punch. This is done by increasing the hold-down force, shown in Figure 3, until it exceeds the forming force, thereby raising the formed part and the die simultaneously.

An experiment was run using forming blanks of 14.5-, 15.0-, and 15.5-inch diameters to make the Dome part trom U.1/U-inch-thick stock. The 14.5-inch-diameter blank was unacceptable because the resulting formed blank was about 0.063 inch too short to make the finish-machined part.

The 15.0- and 15.5-inch-diameter blanks were acceptable.

\section{Cover}

Forming blanks for the Cover part are 14.5-inch in diameter by 0.125 -inch thick. The design of the forming tooling is shown in Figure 6. Initially the clearance between the punch and cavity was 0.115 inch. Since the blank thickness is 0.010 inch greater, this causes good conformance of the formed blank to the tooling because of the high pressures that develop as the beryllium is forced into the die. This approach-having less clearance than stock thickness-is called "ironing" and is

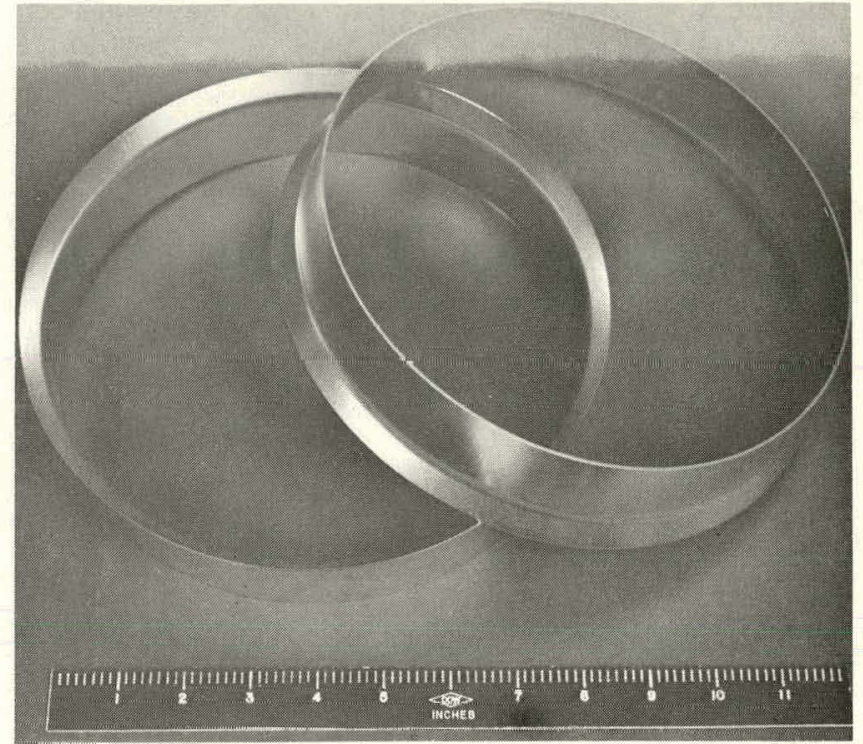

FIGURE 7. Two Typical Covers after Machining and Chemical-Milling.

167611

commonly used for close dimensional control of ferrous parts. The beryllium must thin too much, however, and losses are high when this irnning method is used; consequently the clearance was increased to $0.135 \mathrm{inch}$. This rhange prevented the forming losses, but a number of the parts did not clean up during machining. The area that did not clean up was the blend zone between the conic and cylinder section of the part.

The problem was traced to the stripping practice where the die cavity was first removed and the unsupported formed part was pushed off the punch by the hydraulic system normally used for holddown force. This caused bending of the conic section. The problen was eliminated by pushing the formed part off the punch while keeping the die cavity in contact with the formed part.

Figure 7 shows two, typical, Cover parts after they were machined and etched.

Dish

The initial design of the Dish part called for a short cylindrical section and a larger conic section 


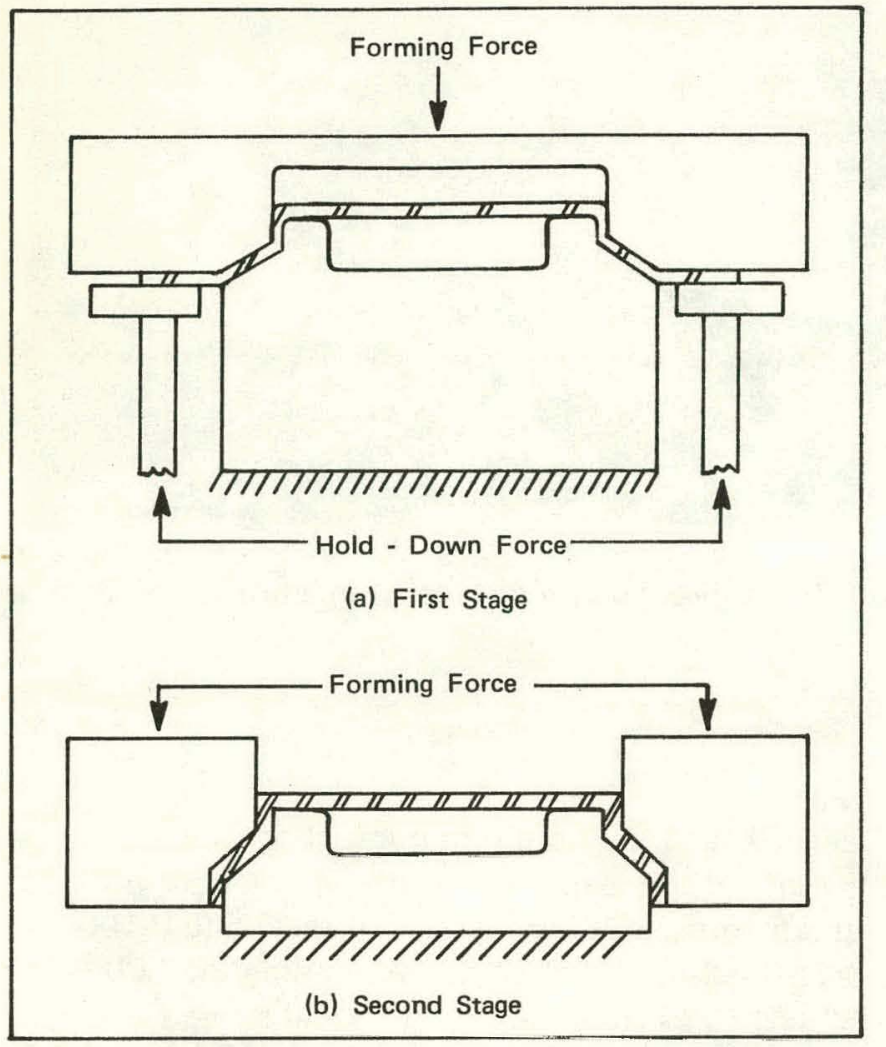

FIGURE 8. Tool Design Used to Make the Dish Part.

that could be machined from a blank formed as shown in Figure 8a. A later design required a second cylinder section, this one at the largediameter end of the conic section. The original tooling is used to make preforms that are trimmed to remove all of the hold-down flange except the small amount needed to make the cylinder section. This small flange is bent $90^{\circ}$ by the tool shown in Figure 8b. Forming-blank and tooling temperatures are nominally the same as used for the other two part types. Shown in Figure 9 are parts from the intermediate and final stages of forming, and a finish-machined, chemically-milled part.

Forming problems in the first stage are caused mostly by cracking as the cylinder section is drawn. The tooling, as shown in Figure 8a, first forms the conic section and then the cylinder ection. The cylinder portion does not draw well ince it is distant from the hold-down flange.
Instead, the cylinder tends to be formed by stretching the nearby metal. This causes severe local thinning and often causes fracture. The problem is minimized by keeping the forming blank hot. The punch originally was solid but was modified by machining the cavity shown in Figure $8 \mathrm{a}$ to help keep the blank hot. This allows the part of a punch in contact with the blank to attain a higher temperature during the preheat. The modification also minimizes contact between punch and blank during forming.

It is possible that a double-action hydraulic press could be used to form the Dish part, which has two cylinder sections. Since a means was already available for making a preform at the time the second cylinder section was added to the design, the two-stage approach shown in Figure 8 was chosen. No significant problems are encountered in the second-stage forming.

The three initial forming blank diameters were $15,15.5$, and 16 inches, all with 0.095 -inch stock thickness. Although all three diameters work adequately, a diameter of 15.5 inches is used because a hot blanking tool exists for that size. Forming 0.030-inch stock directly has been tried, but wrinkling was too severe. This is surprising since the same size blank, 16 inches in diameter by 0.030 inch thick, can be used successfully to make a Dome shape. In the present case, less of the flange is held down, and the portion of the blank between the flange and punch is unsupported, so wrinkling occurs. Laminate forming was tried, but the minor wrinkling that occurred in the outer portion of the flange locked the parts together. Dimensional tolerances require the use of 0.095inch stock, which is machined and chemically milled to the final part thickness of 0.025 inch.

\section{Mechanical Properties}

As mentioned earlier, specifications were changed during the course of the work aimed at developing a production process for making the three beryllium parts from ingot sheet. The minimum mechanical properties that eventually were specified arc: 45,000 psi ultimate, 35,000 psi yield, and $2 \%$ elongation. Rocky Flats' standard ingot sheet 


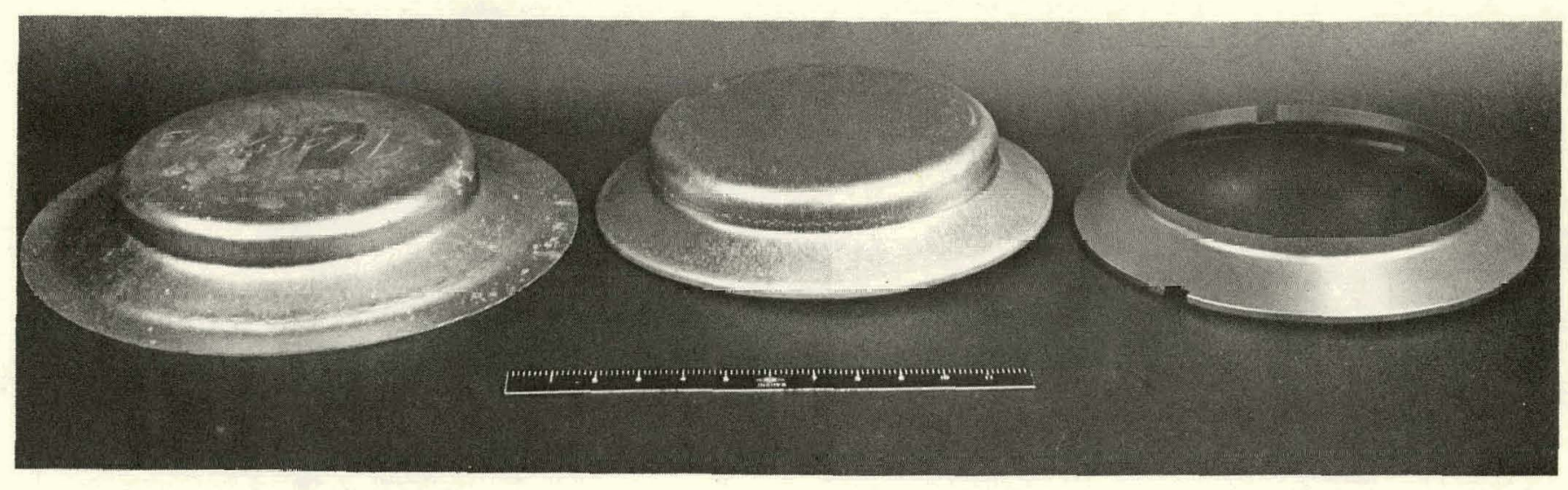

16761-5

FIGURE 9. Shown (left to right) are an Intermediate-Formed Part, a Final-Formed Part, and a Finish-Machined Part.

properties meet the ultimate and elongation requirements, but the yield stress of standard material is typically 26,000 psi. Since the yield stress in the as-rolled condition exceeds 35,000 psi, the temperature of the post-rolling heat treatment was lowered to retain some of the cold work.

There exists a trade-off between yield strength and ductility-the ductility decreasing while the yield strength increases. To learn what heat-treat conditions would retain the yield above 30,000 psi, and would improve the ductility to better than $2 \%$, a number of 0.1 -inch-thick sheets were air-cooled after the last bare-rolling pass. This pass consisted of a $15 \%$ reduction in thickness at $725{ }^{\circ} \mathrm{C}$. Tensile samples were removed from these sheets and heat-treated at temperatures between 650 and $760{ }^{\circ} \mathrm{C}$ for times between 1.5 and 11 hours. Tensile results from one sheet are plotted in Figure 10. The data, derived by $\mathrm{O}$. A. Lee, ${ }^{5}$ are averages of two longitudinal and two transverse tests at each temperature indicated in the figure. All heat treatments were one hour at the indicated temperature. The data in Figure 10 are typical of the trend found using other sheets and other combinations of times and temperatures in the same ranges.

Notice in Figure 10 that when the post-rolling heat-treat temperature is below $675^{\circ} \mathrm{C}$, elongation is below the $2 \%$ minimum requirement of the specification. The ultimate and yield strengths exceed the minimum requirements of the specification in all cases for these one-hour heat treatments. Additional tests of this same 0.100inch-thick sheet reveal that extending the $700{ }^{\circ} \mathrm{C}$ anneal to 11 hours lowers the yield stress to 34,000 psi. These data show that heat-treating the standard material in the temperature range of about 675 to $700{ }^{\circ} \mathrm{C}$ for times of 1.5 to 11 hours should produce adequate mechanical properties.

Having shown that a partial-recrystallization anneal will produce the desired, minimum, mechanical properties in 0.1-inch-thick, ingot-sheet beryllium, it remains to be shown that these same minimums can be obtained in the thicker materials needed for the Dome and Dish components. Such evidence is given in Table 4 for 0.170 -inch-thick material. The data in Table 4 are averages of at least two tests in the longitudinal and transverse directions. The post-rolling, annealing, temperature range of 675 to $705^{\circ} \mathrm{C}$ produces the desired strength and ductility levels. One sheet, $754 \mathrm{~A}$, does not meet the ultimate and yield minimums of $45,000 \mathrm{psi}$ and $35,000 \mathrm{psi}$, respectively. This is an indication that lot-to-lot variations may cause problems in meeting specification requirements.

Data for 0.125-inch-thick stock were not obtained in this phase of the work. Since heat treatment in the range of 675 to $705{ }^{\circ} \mathrm{C}$ is suitable for 0.1 -inchand 0.170 -inch-thick material, it should also be suitable for material of intermediate thickness. 


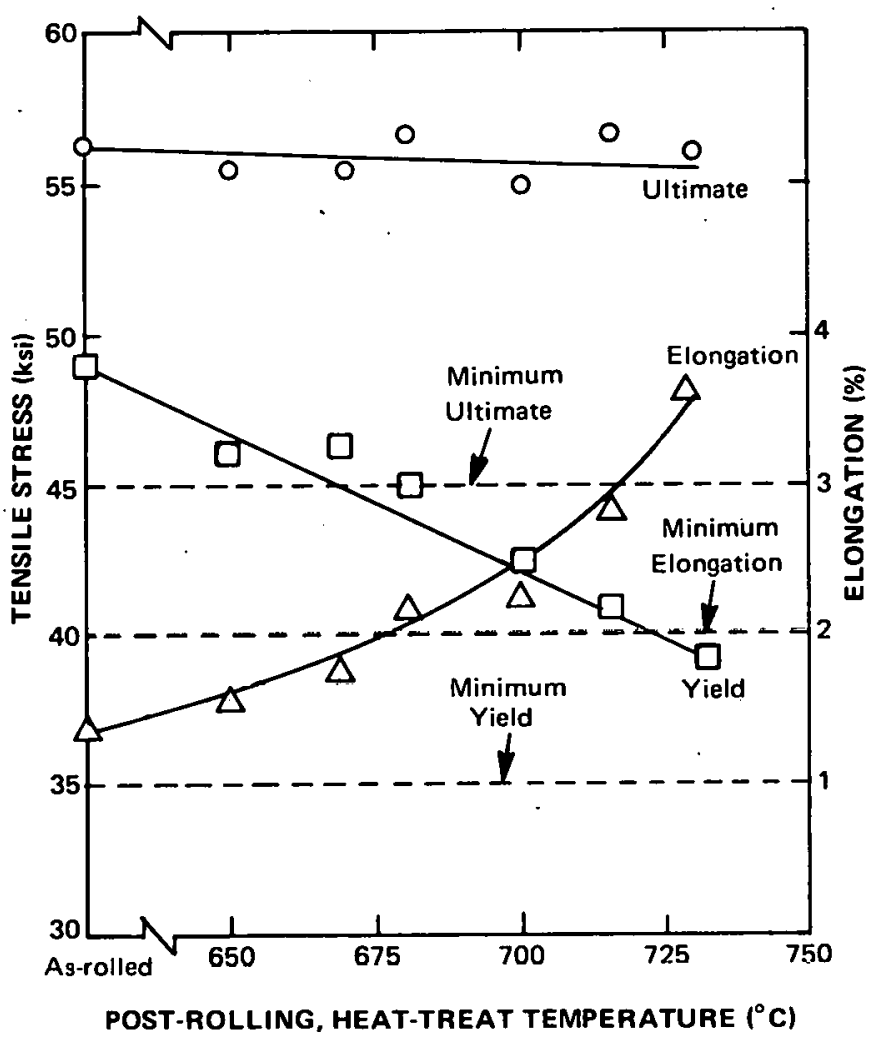

FIGURE 10. Tensile Properties of 0.1-Inch-Thick Ingot Sheet $710 \mathrm{~A}$ as a Function of Post Rolling Heat Treatment.

Now that conditions for retaining ingot sheet in a high yield strength condition are known, it must be shown that the material can be deep-drawn.

Normally, deep-drawing is done with fully annealed ingot sheet, and the forming preheat temperature is $760{ }^{\circ} \mathrm{C}$. Neither of these conditions is compatible with the high yield strength requirement because short times at these temperatures are sufficient to lower the mechanical properties below those desired. It is necessary to determine whether beryllium ingot sheet that has been annealed at 675 to $700{ }^{\circ} \mathrm{C}$ to retain the high yield strength can be deep-drawn at or below $700^{\circ} \mathrm{C}$. Furthermore, it must be verified that properties in the as-formed part still exceeded those minimum requirements of the specification.

Forming blanks were machined from some of the sheet used to develop data for Figure 10 and Table 4. The 0.1-inch-thick material was
TABLE 4. Room Temperature Tensile Properties of Four Sheets of 0.170-Inch-Thick, Ingot-Sheet Beryllium.

\begin{tabular}{|c|c|c|c|c|c|c|c|c|c|}
\hline \multirow{4}{*}{$\begin{array}{l}\text { Sheet } \\
\text { Number }\end{array}$} & \multirow{2}{*}{\multicolumn{3}{|c|}{ Heat Treat Conditions }} & \multicolumn{6}{|c|}{ Tensile Properties } \\
\hline & & & & \multirow{2}{*}{\multicolumn{2}{|c|}{$\begin{array}{c}\text { Ultimate } \\
\text { (ksi) }\end{array}$}} & \multirow{2}{*}{\multicolumn{2}{|c|}{$\begin{array}{l}\text { Yield } \\
\text { (ksi) }\end{array}$}} & \multirow{2}{*}{\multicolumn{2}{|c|}{$\begin{array}{c}\text { Elongation } \\
(\%) \\
\end{array}$}} \\
\hline & \multirow{2}{*}{$\begin{array}{c}\text { Temperature } \\
\left({ }^{\circ} \mathrm{C}\right)\end{array}$} & & \multirow{2}{*}{$\begin{array}{l}\text { Time } \\
\text { (hours) }\end{array}$} & & & & & & \\
\hline & & & & $\mathrm{T}^{*}$ & $L^{* *}$ & $\mathbf{T}$ & $\mathbf{L}$ & $\mathbf{T}$ & $\mathbf{L}$ \\
\hline 906 & 675 & - & 4 & 51.5 & 51.3 & 41.6 & 40.2 & 2.3 & 2.7 \\
\hline 688-B & 705 & - & 2 & 48.3 & 49.4 & 36.8 & 36.7 & 2.7 & 3.1 \\
\hline 754-A & 705 & - & 2 & 40.6 & 40.0 & 31.5 & 31.1 & 2.2 & 1.9 \\
\hline $837-C$ & 705 & - & 2 & 45.0 & 47.4 & 35.6 & 35.4 & 2.3 & 2.4 \\
\hline${ }^{*} \mathrm{~T}-$ & $\begin{array}{l}\text { ansverse } \\
\text { ngitudinal }\end{array}$ & & & & & . & & & \\
\hline
\end{tabular}

TABLE 5. Average Tensile Data from Deep-Drawn, IngotSheet Parts Compared to the Original Sheet Properties.

\begin{tabular}{|c|c|c|c|}
\hline Description & $\begin{array}{c}\text { Ultimate } \\
\text { (ksi) }\end{array}$ & $\begin{array}{l}\text { Yield } \\
\text { (ksi) }\end{array}$ & $\begin{array}{c}\text { Elongation } \\
\text { (\%) }\end{array}$ \\
\hline Sheet $710 \mathrm{~A}$ transverse & 52.0 & 35.4 & 4.0 \\
\hline longitudinal (0.100-inch) & 54.1 & 36.0 & 4.3 \\
\hline $\begin{array}{l}\text { Average of } 12 \mathrm{~T} \text {-bars from two } \\
\text { Dish parts, Sheet } 710 \mathrm{~A}\end{array}$ & 64.9 & 41.9 & 4.0 \\
\hline $\begin{array}{l}\text { Average of } 6 \text { T-bars from one } \\
\text { Dome part drawn from } \\
\text { Sheet } 906\end{array}$ & 54.8 & 44.8 & .1 .7 \\
\hline
\end{tabular}

deep-drawn to the Dish configuration shown in Figure 9, and the 0.170-inch-thick material was deep-drawn into the Dome shape. The Dish parts were preheated to $705{ }^{\circ} \mathrm{C}$ prior to forming, whereas a preheat temperature of $675^{\circ} \mathrm{C}$ was used for the Domes. Tensile bars taken from these formed parts show an increase in yield stress, as is evident from data presented in Table 5. The ductility of the Dome material falls below the $2 \%$ minimum, so a post-forming anneal is needed. Since the yield stress of this material exceeds the minimum by nearly 10,000 psi, such a heat treatment should not reduce the yield below the 35,000 psi minimum.

To summarize this section, a process has been developed for making each of the three beryllium 
parts by deep-drawing ingot sheet. The minimum tensile requirements of the specification are not exceeded by Rocky Flats' standard material because this material is given a full recrystallization anneal after rolling. If, however, a lower temperature, partial recrystallization anneal is used after rolling, this same material will exceed those minimum requirements. Furthermore, this higher strength level can still be retained after deep-drawing.

Having developed a process for making the three beryllium parts out of ingot sheet, there remains a need to establish a process suitable for production. The next section of the report contains the results of a pilot-production run conducted for that purpose.

\section{Pilot Production}

To determine if the process for making the three parts from high yield strength, ingot-source beryllium would be suitable for production, enough material was processed to make 48 sets. A set consists of a Dome, a Cover, and a Dish part. There are basically two measures of production suitability:

(1) Conformance with all chemical, mechanical, and dimensional requirements of the specification.

(2) Process efficiency - the number of parts that meet all of the above requirements compared to the total number of parts processed.

The process can be considered a backup capability if some parts can be made that meet all of the requirements of the specification. It can be considered a viable production process if the process efficiency is reasonably high.

A standard process already exists for making similar parts from ingot-source beryllium. The major difference between that process and this pilot production run is in the yield stress of the ingot sheet. The strength requirements of our standard process allow the use of fully annealed ingot sheet. If such material could be used for the present process, this pilot production run would be simplified greatly if not obviated. Involved would be simply the use of efficiencies based on actual production experience. The need for a higher yield stress renders the ingot sheet more brittle and therefore requires that operations following the bare-rolling step be examined closely for process efficiency. Operations prior to and including bare-rolling already have known production efficiencies.

Monitoring the pilot production run begins logically with the can-rolling step rather than after the bare-rolling step. This is because standard beryllium billets, sheathed in 304 stainless steel, are diverted from the standard process prior to can-rolling and are assigned to the pllot production run. Twenty-eight of these billets, 12 for the Dome, eight for the Dish, and eight for the Cover, are needed to make the 48 sets. Only four forming blanks for the Dome part can be obtained from each billet, whereas six blanks can be obtained from each billet for the other two parts.

Can-rolling of material for the Cover and Dish parts is done according to the standard schedule. The Dome material differs only in that the final two can-rolling passes are skipped, leaving the beryllium at 0.300 -inch thick. All materials are annealed at $760^{\circ} \mathrm{C}$ for 16 hours, then sheared into iwu sluips yes billet measuring nominally 17 by 25 inches. The 25 -inch dimension is stretched during bare-rolling to about 44 inches in the case of the Dome material, 42 inches l'ur the Cuver material, and 52 inches for the Dish material. The different lengths reflect the varying thicknesses to which the Dome, Cover, and Dish materials are rolled. 'These thicknesses are about $0.170,0.125$, and 0.095 inch, respectively.

The post bare-rolling anneal, chosen from results of the process development work, is $675^{\circ} \mathrm{C}$ for four hours. This anncal favors a somewhat higher yield stress at the expense of somewhat lower elongation. If the elongation is too low, it can be improved by an additional heat-treatment at a slightly higher temperature or at $675^{\circ} \mathrm{C}$ for a longer time. This also will lower the yield stress, so care must be taken to minimize these heat-treat conditions. A convenient time to do this supplemental heat treatment is after deep-drawin? 
TABLE 6. Summary of tensile data from a pilot production quantity of ingot-sheet beryllium. Data are arithmetical averages of statistical averages from the various sheets.

No. of Sheets Tested
Nominal Sheet Thickness (in.)
No. of Tests
Test Direction
Ultimate (ksi)
$\quad$ Mean
Standard Deviation
Range
0.2\% Offset Yield (ksi)
Mean
Standard Devlation
Range
Elongation (\%)
Mean
Standard Deviation
Range

\begin{tabular}{cc}
\multicolumn{2}{c}{ DOME } \\
\multicolumn{3}{c}{0.170} \\
\hline 138 & 129 \\
Transverse & Longitudina \\
& \\
46.3 & 48.3 \\
1.13 & 1.32 \\
$43: 4-49.5$ & $45.7-50.4$ \\
& \\
38.7 & 38.9 \\
0.55 & 0.57 \\
$36.6-40.8$ & $36.9-40.5$ \\
& \\
1.7 & 2.0 \\
0.3 & 0.4 \\
$1.3-2.4$ & $1.6-2.5$
\end{tabular}

\begin{tabular}{cc}
\multicolumn{3}{c}{ COVER } \\
\multicolumn{3}{c}{16} \\
\hline 105 & 0.125 \\
Transverse & Longitudina \\
& \\
50.8 & 54.3 \\
0.98 & 1.32 \\
$48.0-53.5$ & $50.5-56.0$ \\
& \\
42.3 & 43.1 \\
0.52 & 0.63 \\
$40.8-44.4$ & $41.9-45.4$ \\
& \\
2.2 & 2.6 \\
0.4 & 0.4 \\
$2.0-2.6$ & $2.2-3.2$
\end{tabular}

\begin{tabular}{cc}
\multicolumn{3}{c}{ DISH } \\
\multicolumn{3}{c}{16} \\
\hline 89 & 0.100 \\
Transverse & Longitudinal \\
& \\
53.7 & 57.7 \\
1.31 & 1.43 \\
$50.8-56.2$ & $56.0-60.0$ \\
& \\
41.5 & 42.6 \\
0.72 & 0.80 \\
$40.2-43.6$ & $41.3-44.0$ \\
& \\
3.6 & 4.0 \\
0.6 & 0.5 \\
$2.6-4.8$ & $3.0-5.0$
\end{tabular}

when some sort of stress-relief anneal is advisable anyway.

\section{Mechanical Properties}

As the data in Table 6 show, the aforementioned strategy is correct. Presented in this table is a summary of a vast number of tensile tests performed to satisfy a sampling requirement of the specification. The average values for yield and ultimate strength for all three part types exceed the minimum specified values of $35,000 \mathrm{psi}$ and 45,000 psi, respectively. The average elongation values for the Dish and Cover exceed the minimum requirement of $2 \%$, but the average transverse elongation of the Dome is only $1.7 \%$. Heat-treating at a slightly higher temperature or for a longer time will improve this ductility, but the yield stress, already uncomfortably close to 35,000 psi, will decrease during this heat treatment. These results, then, show that the chance of meeting the strength requirement at the 0.170 nch thickness needed for the Durne part is not good, especially in terms of production efficiency.
One feature of the data in Table 6 is the low standard deviation seen for the ultimate and yield stresses for all three sheet thicknesses. These values can be used to predict the lower limit of yield and ultimate strengths that are likely to be found in production. For example, it can be said with $99 \%$ confidence that $99 \%$ of the material for the Cover and Dish will exceed the minimum yield and ultimate strength requirements. This information is obtained by noting whether a standard deviation can be multiplied by three, subtracted from its corresponding mean value, and yield a value in excess of the minimum requirement of the specification. In Table 6, for example, the standard deviation is $0.98 \mathrm{ksi}$ for the ultimate tensile strength of the Cover in the transverse direction. The corresponding mean value is 50.8 ksi. Subtracting three standard deviations from that results in a stress of $47.8 \mathrm{ksi}$. Since this $47.8 \mathrm{ksi}$ figure exceeds the minimum requirement of $45,000 \mathrm{psi}$, the $99 \%$ confidence statement above applies. Results of a similar analysis performed for all of the data in Table 6 are presented in Table 7. 
TABLE 7. Statistical Analysis of the Data in Table 6, Showing 99\% Confidence Limits at Three Levels.

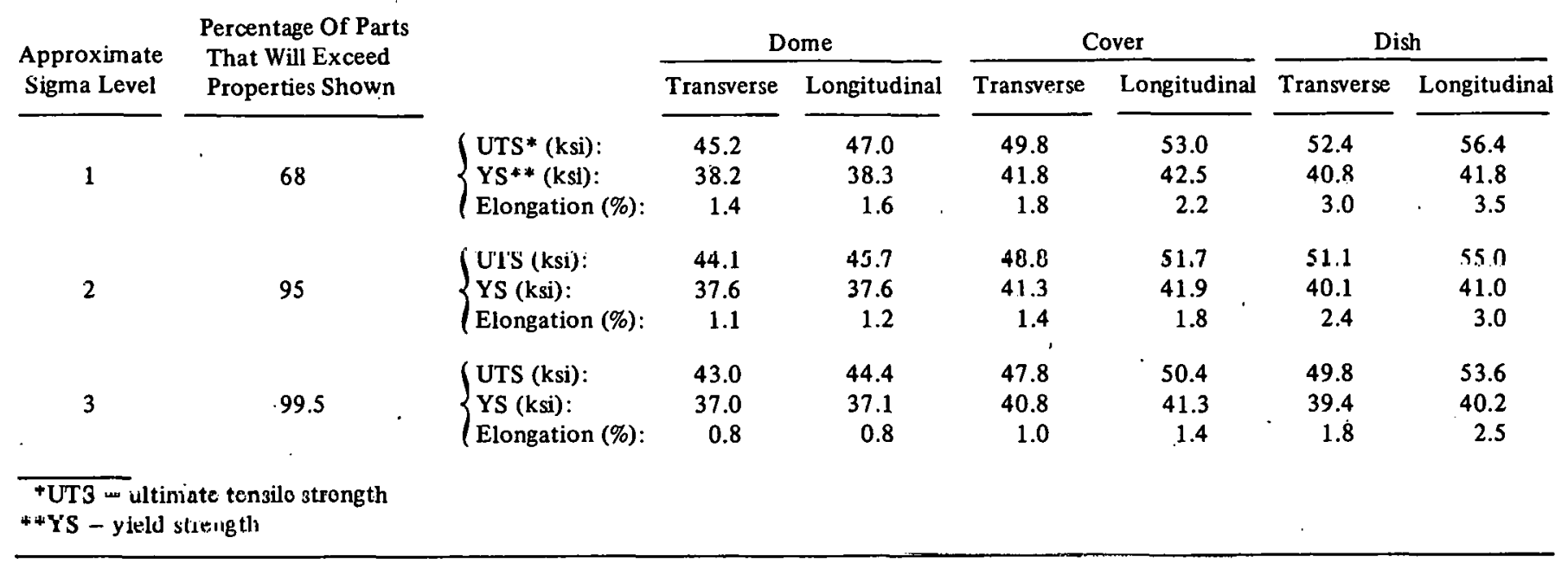

The data in Table 7 confirm that all of the yield values exceed the 35,000 psi minimum requirement at the three-sigma level. Only the Cover and Dish materials exceed the minimum requirement for ultimate tensile strength at the three-sigma level. 'The Dome material in the transverse orientation falls below 45,000 psi at the 2-sigma level.

The elongation values pose the greatest problem because the standard deviations for elongation are so large compared to their corresponding mean values. Subtracting these large standard deviation values from the mean values causes the $2 \%$ minimum to be violated at low sigma levels, as seen in Table 7. None of the material meets the minimum elongation requirement at the three-sigma level, and only the Dish material meets it at the one- and two-sigma levels. This statement is based on the fact that longitudinal and transverse tests both must exceed the minimum to consider that the material as a whole has exceeded it.

As indicated above, elongation values can be improved by the proper choice of a pust-forming stress relief anneal. By raising the mean values for elongation in such a heat treatment, the statistical projection of production behavior will improve. Meanwhile, it should be emphasized that all of the Dish and Cover material in this pilot production run exceeded all minimum requirements of the specification, including the $2 \%$ elongation minimum. This can be seen by the ranges given in Table 6 . Some of the Dome material also cxcccds these requirements.

One final observation about the data in Table 6 is that the lnngitudinal and transverse properties are unıform. In no case du the average slıength properties in the two orientations differ by more than $7 \%$, and the variation of averagc clongation is less than $16 \%$ in these two directions.

To get an idea of the amount of variation of mechanical properties that might be expected within a given part, one sheet at each thickness was tested extensively. The results, shown in Table 8 , closely parallel those for sheet-to-sheet variation given in Table 6. Material for the Dome does not meet the minimum elongation requirement of $2 \%$. All test results for the Cover and Dish material exceed the minimum property requirements. The standard deviations are such that high confidence limits can be placed on exceeding the minimum requirements for ultimate and yield. Confidence that the entire sheet will exceed a $2 \%$ minimum . elongation is much lower. As stated before, a post-forming stress relief can be expected to improve this situation. 


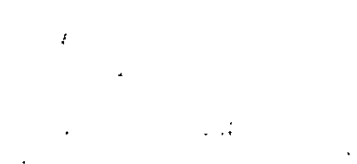

Sheet Number

Sheet Thickness (in.)

No. of Tests

Test Direction

Ultimate (ksi)

Average

Range

$0.2 \%$ Offset Yield (ksi)

Average

Standard Deviation

Range

Elongation (\%)

Average

Standard Deviation

Range
TABLE 8. Tensile data for one sheet of ingot-sheet beryllium for each part type, showing the variation observed within a.single sheet.
DOME

\begin{tabular}{|c|c|c|}
\hline & & 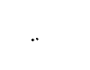 \\
\hline $\begin{array}{c}8 \\
\text { Transverse }\end{array}$ & & $\begin{array}{l}11 \\
\text { itudinal }\end{array}$ \\
\hline
\end{tabular}

46.9

1.26

$44.8-48.9$

38.9
0.44
$38.3-39.5$

39.1

0.38

38.7-39.9

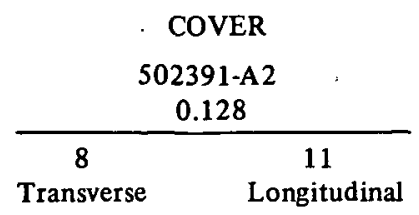

52.6

1.20

$52.1-54.4$

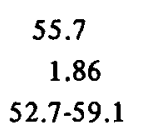

$52.7-59.1$

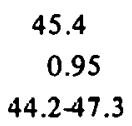

$44.2-47.3$

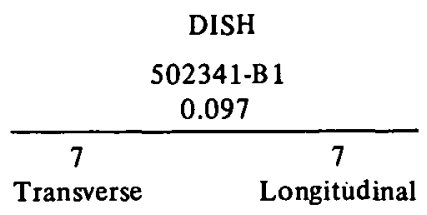

53.4
0.71
$52.9-54.3$
43.0

0.79

$41.8-44.1$

$\begin{array}{llll}43.9-45.1 & 44.2-47.3 & 40.3-44.1 & 41.8-44.1\end{array}$

2.3

0.5

2.0-3.3

2.6
0.4
$8-2.6$

3.1

0.5

2.3- 3.7
3.5

0.4

2.9- 4.1

\section{Losses}

A summary of losses occurring in the pilot production run for each component is given in Table 9. The losses are listed according to the operation responsible, except for dye penetrant and radiographic losses, which were caused by defects from some earlier operation. For comparison, Table 9 includes the number of parts that would be lost if 48 parts of standard, low-yield-strength material were proccsscd. These data are eslimated from actual production experience gained in making similar components from our standard material.

As is evident in Table 9, the loss rate, defined as the number of parts lost divided by the number of parts possible (48) times 100, is high for the three parts. The losses in can-rolling and barerolling are higher than production experience indicates. For these operations, the pilot production run is not a good indicator of actual production results. Dye penetrant losses, which are usually attributed to defects introduced because of roblems with can-rolling, are higher than one might reasonably expect based on production experience. Even with adjusting the losses to account for actual production experience, the loss rates are still $48 \%, 46 \%$, and $35 \%$ for the Dome, Cover, and Dish, respectively. As expected, the reasons for this high loss rate stem from the brittleness that accompanies the high yield stress. Conventional hot blanking cannot be used, for example, because cracking of the blanks results. Even machining of the blanks is difficult because the rolled sheet is not flat and if too much force is used to hold them in the lathe, the blanks will crack. The blanking losses probably are higher than one would experience in production, but the loss rate incurred with machining blanks is bound to exceed that by hot-blanking, even when operator expertise is developed.

Forming losses are seen in Table 9 to be six times greater for the Doine and Cover than that found in the standard process. Part of the increased loss rate is caused by experimentation that had to be done. The first three Dome forming blanks broke at a forming preheat temperature of $675^{\circ} \mathrm{C}$. This temperature had been used successfully for earlier process development work. Raising the preheat 
TABLE 9. Quantity of Parts Rejected During Various Pilot Production Run Operations.

\begin{tabular}{|c|c|c|c|c|}
\hline & Dome & Cover & Dish & $\begin{array}{l}\text { Standard } \\
\text { Process }\end{array}$ \\
\hline Can-Rolling & 6 & 6 & 4 & 5 \\
\hline Bare-Rolling & 1 & 6 & 3 & 1 \\
\hline Blanking* & 4 & 4 & 12 & 0 \\
\hline Forming & 6 & 6 & $-* * *$ & 1 \\
\hline Machining & 3 & 2 & - & 2 \\
\hline Shipping ** & 1 & 1 & - & 1 \\
\hline \multicolumn{5}{|l|}{ Inspecting } \\
\hline Dimensional & 0 & $\mathbf{0}$ & - & 0 \\
\hline Radiographic & 0 & 0 & - & 2 \\
\hline \multirow[t]{2}{*}{ Dye Penetrant } & 1 & 6 & - & 2 \\
\hline & $\bar{a}$ & $\bar{x}$ & $\overline{10}$ & $\overline{1}$ \\
\hline Iotal Losses & 22 & 31 & 19 & 14 \\
\hline Loss Rate (\%) & 46 & 65 & 40 & 29 \\
\hline \multicolumn{5}{|c|}{$\begin{array}{l}\text { *Blanks are obtained by machining the high-strength material and } \\
\text { hot-blanking the standard material. } \\
\text { * "Shipping losses resulted from handling damage as the material } \\
\text { was moved between operations. } \\
\text { " "Work on the project was stopped before this material could } \\
\text { be processed completely. }\end{array}$} \\
\hline
\end{tabular}

temperature to $705^{\circ} \mathrm{C}$ helped, but three more were lost. Four Cover forming blanks were lost hesause the actual furnace temperature was $50^{\circ}$ bclow the $705^{\circ} \mathrm{C}$ indicated by the furnace control thermocouple. 'I he efficiency improved when the faulty thermocouple was replaced.

Forming losses for the Dish part cannot be assessed because the pilot production run was terminated before this operation was completed. The Dish part is the most difficult of the three components to form, owing to the two-stage operation and the rather small radii to which the sheet must be drawn. Therefore, a loss of at least six parts could be anticipated.

Machining losses are caused by cracking of the material and are probably representative of production losses that can be expected. Dimensional losses are rare, despite the use of chemical-milling as the final metal removal step. Some radiographic losses must be expected, as indicated in Table 9, by the standard production experience for this operation.
The difference between the 48 possible parts and the losses shown in Table 9 unfortunately does not equal the number of good Dome and Dish parts. Only five Domes and 15 Covers were completely acceptable. The disparity for the Domes results from four mechanical property rejects, 11 equivalent parts sacrificed for required mechanical testing, and six parts that could not be accounted for. The disparity for the Covers results from one part nol being piocessed at the time work was stopped, and one part being unaccounted for.

In summarizing the losses from various process operations, results of this pilot production run show that a loss rate about double that experienced with the standard, low-yield-strength material must be expected initially. This is caused mostly by the brittle nature of the beryllium when it is given a partial-recrystallization anneal to retain a high yield stress instead of a full-recrystallization anneal 'to develop its full ductility. Undoubtedly the loss rate could be improved as operator expertise in working with this more brittle material improves. Some process development effort directed at the high-loss operations would also improve the efficiency.

\section{DISCUSSION}

The cuuse of this dovolopment work has been strongly dependent upon design changes that occurred frcquently. Originally, sheet-metal fabrication was an extremcly attractive manufacturing route; for example, 18 Domes could have bcon made from a single, hillet. Presently only four such Domes can be madc from the same billet. At one point, no mechanical property requirements existed. Later the requirements of our current ingot-sheet specification were designated. Finally, requirements well beyond those normally found in ingot-sheet and even beyond typical powdersource beryllium were set. Obviously such design changes are necessary or they wouldn't have been made.

The important point relative to this work is that, had the requirements existed from inception, the task would have been approached differently. For example, it is doubtful that an attempt 
TABLE 10. Comparison of Mechanical Properties of Ingot-Source and Powder-Source Beryllium Produced for the Same Three-Part Set.*

\begin{tabular}{|c|c|c|c|c|c|c|}
\hline \multirow[b]{2}{*}{ No. of Tests } & \multicolumn{2}{|c|}{ Dome } & \multicolumn{2}{|c|}{ Cover } & \multicolumn{2}{|c|}{ Dish } \\
\hline & $\begin{array}{c}\text { Ingot Sheet } \\
267\end{array}$ & $\begin{array}{c}\text { Hot-Pressed Block } \\
96\end{array}$ & $\begin{array}{c}\text { Ingot Sheet } \\
219\end{array}$ & $\begin{array}{l}\text { Hot-Pressed Block } \\
996\end{array}$ & $\begin{array}{c}\text { Ingot Sheet } \\
178\end{array}$ & $\begin{array}{l}\text { Hot-Pressed Block } \\
96\end{array}$ \\
\hline \multicolumn{7}{|l|}{ Ultimate (ksi) } \\
\hline Average & 47.3 & 53.1 & 52.6 & 58.4 & 55.7 & 52.2 \\
\hline Standard Deviation & 1.2 & 2.8 & 1.2 & 4.3 & 1.4 & 3.3 \\
\hline Average & 38.8 & 37.9 & 42.7 & 47.3 & 42.0 & 38.9 \\
\hline Standard Deviation & 0.6 & 3.9 & 0.6 & 4.1 & 0.8 & 2.5 \\
\hline \multicolumn{7}{|l|}{ Elongation (\%) } \\
\hline Average & 1.8 & 3.1 & 2.4 & 3.0 & 3.8 & 2.4 \\
\hline Standard Deviation & 0.4 & 0.7 & 0.5 & 1.0 & 0.6 & 0.9 \\
\hline
\end{tabular}

*Data are averages of tests in longitudinal and transverse directions for each material.

would have been made to make the Dome part from ingot sheet because the required thickness limits the number of forming blanks that can be made from a single billet. The cost advantage of ingot-sheet compared to powder-source beryllium increases as thickness decreases because more parts can be made from the same billet. Also, the twostage forming requirement of the Dish part, coupled with the high-yield strength requirement, make the Dish a high-risk item that would not likely be cost-effective in production. Probably the only component that would have been attempted is the Cover part, which is relatively easy to form by deep-drawing, even in the highyield condition.

Efforts continued through the pilot-production stage for all thrce parts since the fabrication technology was developed prior to most of these changes. Also, the higher yield strength requirement could be met easily by simply lowering the post-rolling, heat-treatment temperature. If pilot production proved that an efficient process could be expected, then ingot sheet might be used in production.

Pilot-production results show that the strengths developed in the lower tempeialure heat treatment are acceptable for both the Dish and Cuver, but are only marginal for the Dome. Furthermore, the strengths for all three parts are highly reproducible. In Table 10, these properties are compared to those for a similar quantity of powder-source parts purchased to the same specification and used to make the same three parts. As is evident from the standard deviations in Table 10, the ingot-source material is more reproducible than the powdersource material for any of the three parts. From the standpoint of mechanical properties, the Cover and Dish materials can be considered viable for production. Ingot sheet for the Dome must be considered merely as a backup material.

The loss rate for all three parts in pilot production is higher than for our standard process. This is not unexpected because of the brittleness of the ingot sheet in the high-yield condition compared to the low yield present in the standard material. As operator expertise is gained and more process development work is done, the loss rate for the three-part set should improve to within about $10 \%$ of the loss rate experienced with the standard process.

\section{RECOMMENDATIONS}

Ihis process development and pilot production work has shown that all three beryllium parts can 
be made from ingot sheet. The Cover is the easiest . to make, but the process for both it and the Dish could be considered as viable for production. The Dome process, on the other hand, should be considered as only a backup because of problems in reliably attaining the required mechanical property levels.

The pilot production experience serves to point out important areas for process development. One of these is blanking. Lathe-cutting is a costly route even if the material is in a fully annealed condition; in a recovery-annealed condition, it is extremely difficult to machine forming blanks without cracking them. A hot-blanking method is needed. Since hot-blanking is done easily in the fully annealed condition, perhaps prior to the final rolling pass, the blanks could be cut into a suitable elliptical shape that would elongate to a circle in the final pass. If lathe-cutting must be used, the sheet should first be flattened. This could be done by placing heavy plates on top of the sheets during the post-rolling heat treatment, thereby causing creep-flattening.

Another area of process development is optimization of forming conditions. It is possible that brief exposure to forming temperatures higher than the $70.5^{\circ} \mathrm{C}$ used in the pilot production would improve the forming efficiency without seriously degrading the mechanical properties.
The difficulty in reliably exceeding the minimum requirements of the specification with the thicker Dome material shows the need for improving ingot-sheet properties in thicker sheet. This might best be done by using lower temperatures in the final rolling stages or by obtaining greater total reductions prior to reaching the desired thickness.

\section{REFERENCES}

1. J. L. Frankeny and D. R: Floyd. Ingot Sheet Beryllium Fabrication. RFP-910. The Dow Chemical Company, Rocky Flats Division. Fetruary 9, 1968.

2. Technical Data Book for Ingot Sheet Beryllium. RFP-1605. Dow Chemical U.S.A., Rocky Flats Division. January 4, 1972.

3. M. S. Werkema. "Beryllium Recrystallization Texture." Journal of Applied Crystallography, Vol. 3, No. 265. 1970.

4. G. E. Darwin and J. H. Buddery. Beryllium. Butterworth Scientific Publications. 1960. Pages 225-228.

5. O. A. Lee. Dow Chemical U.S.A., Rocky Flats Division. Private communciation. 